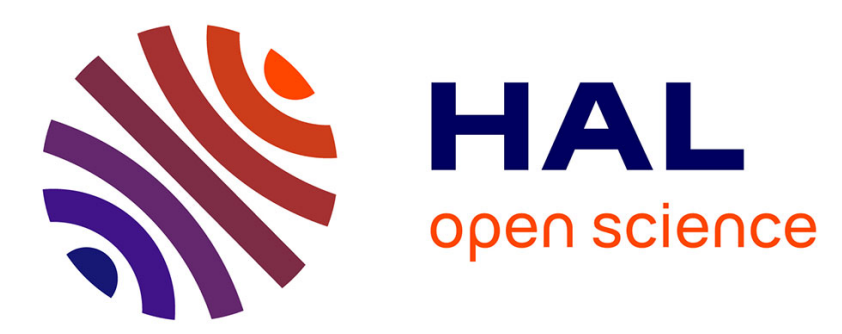

\title{
Antioxidant response of the seagrass when epiphytized by the invasive macroalgae
}

Antoni Sureda, Antonio Box, Jorge Terrados, Salud Deudero, Antoni Pons

\section{To cite this version:}

Antoni Sureda, Antonio Box, Jorge Terrados, Salud Deudero, Antoni Pons. Antioxidant response of the seagrass when epiphytized by the invasive macroalgae. Marine Environmental Research, 2008, 66 (3), pp.359. 10.1016/j.marenvres.2008.05.009 . hal-00501971

\section{HAL Id: hal-00501971 https://hal.science/hal-00501971}

Submitted on 13 Jul 2010

HAL is a multi-disciplinary open access archive for the deposit and dissemination of scientific research documents, whether they are published or not. The documents may come from teaching and research institutions in France or abroad, or from public or private research centers.
L'archive ouverte pluridisciplinaire HAL, est destinée au dépôt et à la diffusion de documents scientifiques de niveau recherche, publiés ou non, émanant des établissements d'enseignement et de recherche français ou étrangers, des laboratoires publics ou privés. 


\section{Accepted Manuscript}

Antioxidant response of the seagrass Posidonia oceanica when epiphytized by the invasive macroalgae Lophocladia lallemandii

Antoni Sureda, Antonio Box, Jorge Terrados, Salud Deudero, Antoni Pons

PII:

S0141-1136(08)00163-3

DOI:

10.1016/j.marenvres.2008.05.009

Reference:

MERE 3261

To appear in:

Marine Environmental Research

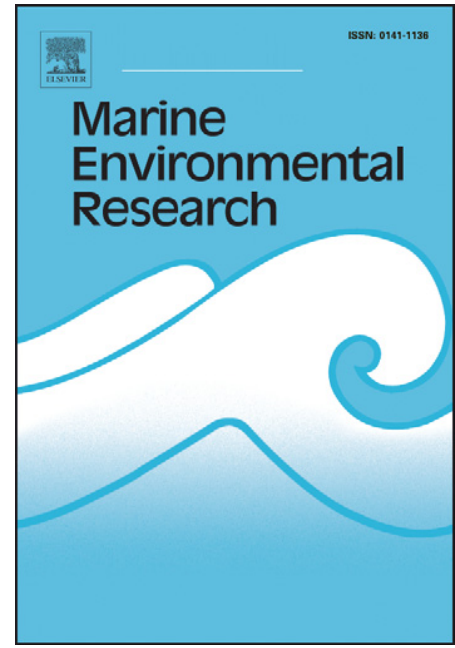

Received Date: $\quad 11$ January 2008

Revised Date: $\quad 20$ May 2008

Accepted Date: $\quad 21$ May 2008

Please cite this article as: Sureda, A., Box, A., Terrados, J., Deudero, S., Pons, A., Antioxidant response of the seagrass Posidonia oceanica when epiphytized by the invasive macroalgae Lophocladia lallemandii, Marine Environmental Research (2008), doi: 10.1016/j.marenvres.2008.05.009

This is a PDF file of an unedited manuscript that has been accepted for publication. As a service to our customers we are providing this early version of the manuscript. The manuscript will undergo copyediting, typesetting, and review of the resulting proof before it is published in its final form. Please note that during the production process errors may be discovered which could affect the content, and all legal disclaimers that apply to the journal pertain. 


\section{ACCEPTED MANUSCRIPT}

Antioxidant response of the seagrass Posidonia oceanica when epiphytized by the invasive macroalgae Lophocladia lallemandii

Antoni Sureda ${ }^{1}$, Antonio Box ${ }^{2}$, Jorge Terrados ${ }^{3}$, Salud Deudero ${ }^{2}$ and Antoni Pons ${ }^{1}$

1) Laboratori de Ciències de l'Activitat Física, Departament de Biologia Fonamental i

Ciències de la Salut, Universitat de les Illes Balears, Ctra. Valldemossa Km 7.5.E07122-Palma de Mallorca, Illes Balears, Spain.

2) Laboratorio de Biología Marina, Universidad Islas Baleares- IMEDEA. Ctra.

Valldemossa Km 7.5 Palma de Mallorca, Illes Balears, Spain.

3) Instituto Mediterráneo de Estudios Avanzados, IMEDEA (CSIC-UIB). C/ Miquel

Marques 21 E-07190, Baleares, Spain.

to whom correspondence should be addressed:

Dr. Antoni Sureda

e-mail: tosugo@hotmail.com

Guillem Colom, Campus Universitari, Ctra. Valldemossa, km 7.5

Laboratori de Ciències de l'Activitat Física, Departament de Biologia Fonamental i

Ciències de la Salut

07122 Palma de Mallorca, Spain

Tel: +34971173452

Fax: +34971173184 


\title{
ACCEPTED MANUSCRIPT
}

\begin{abstract}
The aim was to evaluate the antioxidant defences and the occurrence of oxidative damage in $P$. oceanica under a stress situation due to the epiphytism of the invasive macroalgae Lophocladia lallemandii. P. oceanica leaves were collected in the absence (control station) and in the presence of the epiphytic algae L. lallemandii and the antioxidant enzyme activities, markers of oxidative damage, and hydrogen peroxide production were determined. Antioxidant enzyme - catalase, glutathione peroxidase and superoxide dismutase - activities were significantly higher in Posidonia epiphytized by L. lallemandii. Malondialdehyde, protein carbonyl derivates, and glutathione levels were also higher in L. lallemandii-epiphytized P. oceanica leaves compared to control samples. The production of hydrogen peroxide was also significantly increased when Posidonia was epiphytized by L. lallemandii. The invasion of $P$. oceanica meadows by L. lallemandii appeared to induce oxidative stress in the seagrass as evidenced by increased levels of oxidative stress markers and antioxidant defences.
\end{abstract}

Keywords: Posidonia oceanica, invasive species, Lophocladia lallemandii, reactive oxygen species, lipid peroxidation, Western Mediterranean 


\section{ACCEPTED MANUSCRIPT}

\section{Introduction}

The endemic Posidonia oceanica (L.) Delile is the most widespread seagrass species in the Mediterranean Sea, where it forms large meadows from the surface to 40 m depths (Buia et al., 2000). P. oceanica is considered a very important ecosystem and is recognized by the European Habitats Directive (92/43/CEE) as a habitat of priority interest. Nevertheless, meadows of $P$. oceanica have suffered a regression in several coastal areas (Marba and Duarte, 1997; Ruiz and Romero, 2003). Because of the requirements of $P$. oceanica meadows for light and sediment conditions, they are affected by different processes such as bottom-trawling fisheries, sedimentation, increased water turbidity, coastal constructions, urban and industrial waste and more recently the colonization by invasive species (Ballesteros et al., 2007).

Invasive macroalgae are a current problem around all coastal waters and eight species of invasive macroalgae have been identified in the Western Mediterranean, among them Lophocladia lallemandii (Montagne) F. Schmitz (Boudouresque and Verlaque, 2002). The red alga L. lallemandii considered an alien species in the Mediterranean Sea and probably introduced via the Suez Channel, is widespread throughout the tropics and subtropics (Boudouresque and Verlaque, 2002).

Lophocladia lallemandii is very aggressive invasive species and it settles over all types of substrates (bare bedrocks, macroalgae on rocky bottoms, P. oceanica seagrass meadows, and coralligenus communities) affecting the invertebrate community (Ballesteros, 2006). L. lallemandii displays a particular pattern of invasion in $P$. oceanica meadows. Initially, the alga settles on rhizomes and occasionally over old leaves, growing as an epiphyte, and finally, overgrows completely the seagrass and macroalgal communities. Nowadays, L. lallemandii in Balearic Islands is invading all types of substrates by fragment dispersion and sexual reproduction. The invasion of $L$. 


\section{ACCEPTED MANUSCRIPT}

lallemandii induces a decrease in size and weight of the $P$. oceanica shoots, leaf chlorosis, leaf necrosis, and finally, shoot death of $P$. oceanica plants (Ballesteros et al., 2007). The potential of invasion by L. lallemandii is very high, forming dense and extense mats inside the seagrass meadows.

During normal cellular activities, various processes inside the cells produce reactive oxygen species (ROS) (Halliwell and Gutteridge, 1999). Some of the most common ROS are hydrogen peroxide $\left(\mathrm{H}_{2} \mathrm{O}_{2}\right)$, superoxide anion $\left(\mathrm{O}_{2}{ }^{-}\right)$, and hydroxyl radical $\left(\mathrm{OH}^{-}\right)$. These compounds, when produced at high enough rates, can damage cellular components such as lipids, proteins and DNA. Cells contain a complex network of antioxidant defenses that scavenge or prevent the generation of ROS, and repair or remove the damaged molecules (Elias et al., 1999). The antioxidant system involves enzymes such as superoxide dismutase (SOD), catalase (CAT) and glutathione peroxidase (GPX) that act by detoxifying the ROS generated. If the ROS production is excessive or the antioxidant system is overwhelmed, a situation of oxidative stress appears. High irradiance and temperature or carbon deficiency may increase the production of ROS and cause oxidative stress in photosynthetic organisms (Asada, 1999; Choo et al., 2004). In this way, the tolerance to stress of marine algae seems to be related to the metabolism of ROS.

Exposure to toxins and contaminants also increases the production of ROS in marine organisms (Shi et al., 2005). In previous work, we have shown that the presence of the invasive macroalgae Caulerpa taxifolia induces oxidative stress in the gastropoda Bittium reticulatum and also in the labridae fish Coris julis. Lophocladia sp. are a source of lophocladines, alkaloids with cytotoxic effects (Gross et al., 2006). The epiphitism of L. lallemandii over $P$. oceanica reduces light availability, hampers water 


\section{ACCEPTED MANUSCRIPT}

movement enhancing sediment trapping, organic and nutrient enrichment and oxygen consumption (Ballesteros et al. 2007).

The aim of the present work was to evaluate the antioxidant defences of Posidonia oceanica under an a priori stress situation due to the epiphytism of Lophocladia lallemandii (Ballesteros et al., 2007). The results will represent a useful tool to understand the physiological response of the seagrass to the epiphytism by that invasive macroalgae and to explain the increased shoot mortality observed previously (Ballesteros et al., 2007).

\section{Materials \& Methods}

\section{Sampling location}

Sampling of Posidonia oceanica in the absence (control station) and in the presence of the epiphyte algae Lophocladia lallemandii was performed in October 2006 in Dragonera Island (Mallorca, Spain, Western Mediterranean) by SCUBA diving at 7 meter depth. Both sampling areas selected for antioxidant analysis had P. oceanica meadows, with similar seagrass coverage, and were separated by hundreds of meters $\left(39^{\circ} 34^{\prime} 32.88^{\prime \prime} \mathrm{N}, 2^{\circ} 20^{\prime} 54.46^{\prime \prime E}\right)$. Eight leaf samples of $P$. oceanica were collected in epiphyted and non-epiphyted conditions, and these samples were immediately frozen in liquid nitrogen and maintained at $-80^{\circ} \mathrm{C}$ until biochemical analysis. On the epiphyted Posidonia leaves and shoots, the coverage of L. lallemandii was quantified within 4 quadrants of $20 \times 20 \mathrm{~cm}$ and eight samples were collected for algal biomass determination.

Prior to biochemical analysis, Posidonia leaves were carefully separated from the epiphytes. The shoots used in our enzyme determinations did not show any signs of damage by grazing activity. The basal parts of Posidonia leaves were rinsed with 


\section{ACCEPTED MANUSCRIPT}

distilled water and crushed in a mortar containing liquid nitrogen. The samples were homogenized in five volumes (w/v) of $50 \mathrm{mM}$ Tris-HCl buffer, $1 \mathrm{mM}$ EDTA, $\mathrm{pH}$ 7.5. Homogenates were centrifuged at $9000 \mathrm{xg}, 10 \mathrm{~min}, 4^{\circ} \mathrm{C}$ to remove cell debris, nuclei and mitochondria. Supernatants were used for biochemical assays. All biochemical analyses were expressed per mg protein measured by using a colorimetric commercial kit $\left(\right.$ Biorad $^{\circledR}$ ) with Bovine Serum Albumin (BSA) as a standard.

\section{Sea grass shoot density}

Shoot density of Posidonia oceanica were estimated at both stations (epiphytized and non-epiphytized) employing a 40 x $40 \mathrm{~cm}$ frame. The number of shoots were calculated for plots of $P$. oceanica without epiphytes $(\mathrm{n}=10)$ and for plots of $P$. oceanica epiphytized by L. lallemandii $(\mathrm{n}=10)$. These results were compared with P. oceanica shoot densities estimated in the same sampling areas with similar methodology in October 2002.

\section{Lipid peroxidation}

Lipid peroxidation of $P$. oceanica leaves was determined by measuring the amount of total malondialdehyde (MDA) (Esterbauer et al., 1991), analyzed by a colorimetric assay kit (Calbiochem ${ }^{\circledR}$, San Diego, CA, USA). Briefly, samples or standards were placed in glass tubes containing n-methyl-2-phenylindole $(10,3 \mathrm{mM})$ in acetonitrile:methanol (3:1). $\mathrm{HCl} 12 \mathrm{~N}$ was added and the samples were incubated one hour at $45^{\circ} \mathrm{C}$. The absorbance was measured at $586 \mathrm{~nm}$. MDA was quantified using a standard curve of known concentrations of MDA. In order to avoid possible interferences by photosynthetic pigments we made a blank with extract plant without reagents.

\section{Protein Carbonyl derivatives}




\section{ACCEPTED MANUSCRIPT}

Protein carbonyl derivatives were measured in $P$. oceanica leaves by an adaptation of the method of Levine et al. (1994). Samples were deproteinised with metaphosphoric acid. Precipitates were resuspended with 2,4-dinitrophenylhydrazine (DNPH) $10 \mathrm{mM}$, and incubated for $60 \mathrm{~min}$ at $37^{\circ} \mathrm{C}$. Then, samples were precipitated with $20 \%$ trichloroacetic acid, and centrifuged for $10 \mathrm{~min}$ at $1,000 \mathrm{x} \mathrm{g}$ and $4^{\circ} \mathrm{C}$. The precipitate was washed twice with ethanol:ethyl acetate (1:1). Guanidine $6 \mathrm{M}$ in phosphate buffer $2 \mathrm{mM}$, pH 2.3 was added to the precipitate, and samples were incubated for $40 \mathrm{~min}$ at $37^{\circ} \mathrm{C}$. Finally, samples were centrifuged for $5 \mathrm{~min}$ at $3,000 \mathrm{x} \mathrm{g}$ at $4^{\circ} \mathrm{C}$ to clarify the supernatant. The concentration of carbonyl groups was calculated from the absorbance at $340 \mathrm{~nm}$ using the value of $22,000 \mathrm{M}^{-1} \mathrm{~cm}^{-1}$ for the molar absorption of aliphatic DNPH derivatives. Samples were analysed against a blank of guanidine solution.

\section{GSH concentration}

GSH was measured by the formation of coloured adducts upon reaction with $0.62 \mathrm{mM} 5,5^{\prime}$-dithio-bis(2-nitrobenzoic acid) solution (DTNB). The absorbance of DTNB-treated samples at $412 \mathrm{~nm}$ was calculated using GSH as standard and reported as nmol GSH/mg protein.

\section{Antioxidant enzyme activities}

Catalase, GPX and SOD enzyme activities were determined with a Shimadzu UV-2100 spectrophotometer at $20^{\circ} \mathrm{C}$. Catalase activity was estimated by recording the decrease in the absorbance of $\mathrm{H}_{2} \mathrm{O}_{2}$ in $50 \mathrm{mM}$ phosphate buffer monitored at $234 \mathrm{~nm}$ (Aebi, 1984). GPX activity was measured using an adaptation of the spectrophotometric method of Flohé and Gunzler (1984). The reaction mixture contained GSH, glutathione reductase, $\mathrm{NaN}_{3}$ and $\mathrm{NADPH}$. The rate of reaction was measured by the decrease in $\mathrm{NADPH}$ at $340 \mathrm{~nm}$ using $\mathrm{H}_{2} \mathrm{O}_{2}$ as the substrate. SOD activity was measured by an 
adaptation of the method of McCord \& Fridovich (1969). The xanthine/xanthine oxidase system was used to generate the superoxide anion. This anion produces the reduction of cytochrome $\mathrm{c}$, which was monitored at 550nm. The superoxide dismutase present in the sample removes the superoxide anion and reduces the amount of reduced cytochrome c.

\section{$\mathrm{H}_{2} \mathrm{O}_{2}$ production}

$\mathrm{H}_{2} \mathrm{O}_{2}$ production was assayed in Posidonia oceanica leaf homogenates by measuring the increase in fluorescence (530 $\mathrm{nm}$ excitation, $590 \mathrm{~nm}$ emission) due to the reaction of Amplex Red reagent (Molecular probes ${ }^{\circledR}$ ) with $\mathrm{H}_{2} \mathrm{O}_{2}$ in the presence of horseradish peroxidase. Assays were performed at $25^{\circ} \mathrm{C}$ in a $96-$ well microplate fluorimeter (FLx800, Bio-tek instruments ${ }^{\circledR}$ ). Homogenates were added in each well containing horseradish peroxidase $0.1 \mathrm{U} \mathrm{ml}^{-1}$ and Amplex Red reagent $10 \mu \mathrm{M}$. The rate of $\mathrm{H}_{2} \mathrm{O}_{2}$ production was calculated using a standard curve of $\mathrm{H}_{2} \mathrm{O}_{2}$.

\section{Statistical Analysis}

Statistical analysis was carried out using a statistical package (SPSS 14.0 for Windows 9 . The statistical significance was compared by one-way analysis of variance (ANOVA). Results are expressed as mean \pm S.E.M. and $p<0.05$ was considered statistically significant.

\section{Results}

Mean biomass of invasive Lophocladia lallemandii. There was no presence of L. lallemandii in P. oceanica collected at the control site. L. lallemandii biomass expressed as dry weight in leaves of epiphytized $P$. oceanica was $16.3 \pm 2.1 \mathrm{~g} \mathrm{~m}^{-2}$. The ratio between $P$. oceanica biomass (including leaves, sheaths and rhizomes) versus $L$. lallemandii biomass was 10.7 (174 g P. oceanica DW/ 16.17 g L. lallemandii DW). 


\section{ACCEPTED MANUSCRIPT}

Posidonia oceanica shoot densities. There was no evidence of significant differences in P. oceanica shoot densities collected at the control station in 2002 and in 2006 (Figure 1). The presence of L. lallemandii induced an important reduction of shoot densities in medium spatial scale with significant differences between epiphytized $P$. oceanica plots and control plots $\left(270 \pm 10\right.$ shoots $/ \mathrm{m}^{2}$ and $571 \pm 15$ shoots $/ \mathrm{m}^{2}$ respectively, $p<0.05)$.

Markers of oxidative damage. The concentration of MDA and the concentration of protein carbonyl derivatives (Table 1) were significantly higher in the leaves of $P$. oceanica epiphytized by $L$. lallemandii compared to the leaves of $P$. oceanica without the epiphyte $(p<0.05)$.

GSH concentration. The leaves of $P$. oceanica epiphytized by L. lallemandii had a higher GSH concentration (Table 1) than the leaves of $P$. oceanica without the epiphyte $(p<0.05)$.

Antioxidant enzyme activities. All antioxidant enzyme activities measured Catalase, GPX and SOD - (Table 1) were significantly higher in the leaves of $P$. oceanica epiphytized by $L$. lallemandii compared to the leaves of P. oceanica control shoots $(p<0.05)$.

$\mathrm{H}_{2} \mathrm{O}_{2}$ production. We measured the $\mathrm{H}_{2} \mathrm{O}_{2}$ production, and the results, expressed as pmols of $\mathrm{H}_{2} \mathrm{O}_{2} \mathrm{mg}$ protein ${ }^{-1} \mathrm{~min}^{-1}$, are presented in Table 1. Samples of P. oceanica with the epiphyte L. lallemandii generated more $\mathrm{H}_{2} \mathrm{O}_{2}$ than samples where this epiphyte was absent $(p<0.05)$.

\section{Discussion}

Shoots of $P$. oceanica were collected in Dragonera Island (Western Mediterranean) from two contrasting conditions, with and without the invasive 


\section{ACCEPTED MANUSCRIPT}

epiphytic macroalgae Lophocladia lallemandii. Visual inspection of L. lallemandii epiphytized $P$. oceanica indicated that the epiphytized shoots had shorter leaves and lower shoot densities (Figure 2) than in those locations where the shoots were not epiphytized by L. lallemandii. Our observations were consistent with those of Ballesteros et al. (2007) that showed a decrease in size and weight of shoots, as well as leaf chlorosis, leaf necrosis, and shoot death in those shoots epiphytized by $L$. lallemandii.

The epiphytism of L. lallemandii over $P$. oceanica leaves is mainly in the summer and autumn due to the tropical affinities of genus Lophocladia, with higher summer temperatures suitable for its development (Cebrian and Ballesteros, 2007). L. lallemandii reduces its epiphytism rates during winter and spring, mainly disappearing from leaves and remaining restricted to the rhizome stratum. Therefore, the effect of $L$. lallemandii on $P$. oceanica is mainly confined to periods of high water temperatures, whereas during winter and spring, $P$. oceanica do no longer suffer the negative effects of $L$. lallemandii (Ballesteros et al., 2007). Consequently the antioxidant response measured due to the epiphytism is temporally restricted to summer and autumn.

Seagrasses are known to be affected by the epiphytic growth of benthic algae (Ozimek et al., 1991). Hypoxic or anoxic conditions induced by shading reduced photosynthetic activity and leaf biomass, and can prevent the adequate oxygenation of rhizomes thus affecting the vitality of $P$. oceanica (Ruiz and Romero, 2001). The nearly complete coverage of $P$. oceanica leaves by $L$. lallemandii is likely to reduce the irradiance reaching the seagrass, especially the young leaves. Ruiz and Romero (2001) described that the reduction of light availability promoted a reduction of the photosynthetic activity and a decrease of the sucrose content of $P$. oceanica. 


\section{ACCEPTED MANUSCRIPT}

Cellular antioxidant status is used to evaluate the ability of organisms to resist an environmental stress situation. It was well established that cyanobacterial toxins produce adverse effects in aquatic plants, as evidenced by increased antioxidant enzymes and reduced photosynthetic oxygen production (Mitrovic et al., 2004). It has been published that lophocladines from Lophocladia exhibited cytotoxicity to several human cell lines (Gross et al., 2006). Lipid peroxidation, measured by the amount of MDA, and the levels of protein carbonyl derivatives are some of the most important results of an attack by hydroxyl radicals. These variables are considered markers of cellular damage (Geffard et al., 2001). P. oceanica epiphytized by L. lallemandii appeared to undergo an oxidative stress, since a significant increase in both MDA levels and protein carbonyl derivates were observed. The antioxidant mechanisms seemed to have been overwhelmed, since the antioxidant enzyme activities were not strong enough to prevent membrane lipid peroxidation and protein oxidation.

GSH is a multifunctional thiol tri-peptide found in all eukaryotes and it is involved in the defence against metal-stress (Okamoto et al., 2001). Its functions include: a) antioxidant activity against oxiradicals (Alscher, 1989), which are induced by some metals, b) the primary precursor for the formation of metal-complexing thiol peptides, phytochelatins (Cobbett and Goldsbrough, 2002) and c) complexation of metals by sulphydryl coordination (Scott et al., 1993). In the present work, GSH concentration in $P$. oceanica increased in the presence of $L$. lallemandii, probably as a response to this stressful situation. GSH is tightly regulated in $P$. oceanica leaves in order to maintain sufficiently high concentrations for other essential cellular functions.

Chemical defences are a well known mechanism in algae to avoid herbivorism and epiphytism (Dumay et al., 2002; Erickson et al., 2006). It has been evidenced that algae produce higher concentrations of defensive compounds in areas subject to high 


\section{ACCEPTED MANUSCRIPT}

herbivore pressure (Paul and Fenical, 1986). Aside from the synthesis of defensive metabolites, the production of ROS has been shown to have a significant contribution towards the survival of algae against pathogens (Bouarab et al., 2001; Kupper et al., 2002), It has been suggested that the release of $\mathrm{H}_{2} \mathrm{O}_{2}$ may act as a chemical defence against herbivores and epiphytes or as an allochemical in direct competition with other algal species (Choo et al., 2005). Collén and Pedersen (1994) also reported the role of $\mathrm{H}_{2} \mathrm{O}_{2}$ in the formation of volatile halogenated defensive compounds. $\mathrm{H}_{2} \mathrm{O}_{2}$ is a longerlasting reactive species electrically neutral and is able to pass through cell membranes. Its longevity allows $\mathrm{H}_{2} \mathrm{O}_{2}$ to reach considerable distances from its site of production (Wojtaszek, 1997). It has been demonstrated that ROS can be produced extracellularly in terrestrial plants and in the marine macroalga Dasycladus vermicularis (Scropoli) Krasser through the reaction of a cell wall-bound peroxidase and plasma membrane bound NADPH oxidase (Bolwell et al., 1998; Ross et al., 2006). In fact, the use of specific inhibitors of NADPH oxidase has confirmed the presence of an NADPH oxidase system in various algal lineages (Kupper et al., 2002; Ross et al., 2005). $\mathrm{H}_{2} \mathrm{O}_{2}$ has also been known to act as cellular messenger for the induction of the antioxidant defence system in response to oxidative stress (Forman and Torres, 2002). Mitrovic et al. (2004) indicated that exposure of the aquatic plant Lemna minor to cyanotoxins increases the formation of ROS during the biotransformation of the toxin. The increase in $\mathrm{H}_{2} \mathrm{O}_{2}$ production in epiphyted $P$. oceanica suggest that oxidative stress is a mechanism involved in the interaction of the invasive $L$. lallemandii and the seagrass $P$. oceanica. This increase of ROS could be a defensive mechanism activated in the situation of host-epiphyte competence induced by epiphytism, the presence of lophocladines in the environment or the interaction of the two factors. 


\section{ACCEPTED MANUSCRIPT}

Antioxidant defence enzymes play an important role in cellular antioxidant defence systems and protect from oxidative damage. The increase of catalase, SOD and GPX activities is related to the higher production of reactive oxygen species, which will be detoxified as result of the antioxidant reactions. Temperature, salinity, heavy metals and pollutants are important environmental stressors that can induce an activation of antioxidant mechanisms in several species (Ferrat et al., 2003; Monserrat et al., 2006). It was shown that seagrasses and particularly $P$. oceanica are very sensitive to variations in environmental quality (Ferrat et al., 2003). The great increase in MDA and carbonyl derivatives could be indicative of hydroxyl radical attack altering the structres of lipids and proteins. The higher increase in antioxidant enzyme activities were in GPX problably as a result of its dual function, detoxifying lipid hydroperoxides to alcohols and reducing free $\mathrm{H}_{2} \mathrm{O}_{2}$ to water. Mitrovic et al. (2004) demonstrated an inhibition of photosynthetic oxygen production, which was dependent on the anatoxin-a concentration. This reduction may have been due to the increased formation of ROS and, consequently, to the oxygen consumption during the toxin biotransformation. Increasing levels of ROS in P. oceanica under L. lallemandii-epiphytism overwhelmed the antioxidant response and induced cellular damage, as the increased lipid peroxidation and protein oxidation confirm. These results indicate that the damage caused to lipids and proteins was not induced by a breakdown of the system responsible for reducing ROS, because antioxidant enzyme activities are increased in the presence of the epiphyte. Instead the oxidative damage was caused by increased oxidative stress through increased production of ROS. Therefore, it can be hypothesized that the antioxidant status of $P$. oceanica may play a role in the control of epiphytism. As the epiphytes cover a greater part of the host plants, Posidonia's photosynthetic 
performance and equally its antioxidant status will diminish. This will result in the deterioration of the seagrass meadows.

In conclusion, the regression of Posidonia oceanica seagrass meadows has been related to anthropogenic impacts such as eutrophication, coastal constructions, anchoring, dumping, and sewage loads, among others. Biological effects are also contributing to seagrass decline, through the interaction of the endemic seagrass $P$. oceanica with invasive species of macroalgae such as Caulerpa spp. and Lophocladia lallemandii. The epiphytism of Lophocladia lallemandii over the Posidonia oceanica leaves constitutes a new impact to the seagrass meadows, resulting in oxidative stress and cellular damage that could induce increased shoot mortality.

\section{Acknowledgements}

This work was supported by the project "Macroalgas marinas invasoras en las islas Baleares: Evaluación de riesgos y efectos en comunidades bentónicas" CTM200501434/MAR, and by Direcció General de Recerca, Desenvolupament Tecnològic i Innovació de la Conselleria d’Economia, Hisenda i Innovació “Acció Especial, 2007 Aplicacions dels biomarcadors en el musclo Mytilus galloprovincialis". 


\section{References}

Aebi, H.E., 1984. Catalase in vitro. Methods in Enzymology, 105, 121-126.

Agostini, S., Desjobert, J.M., Pergent, G., 1998. Distribution of phenolic compounds in the seagrass Posidonia oceanica. Phytochemistry, 48, 611-617.

Alscher, R.G., 1989. Biosynthesis and Antioxidant Function of Glutathione in Plants. Physiologia Plantarum, 77, 457-464.

Asada, K., 1999. The water-water cycle in chloroplasts: Scavenging of active oxygens and dissipation of excess photons. Annual Review of Plant Physiology and Plant Molecular Biology, 50, 601-639.

Ballesteros, E., 2006. Mediterranean coralligenous assemblages: a synthesis of present knowledge. Oceanography and Marine Biological. An Annual Review, 44, 123-195.

Ballesteros, E., Cebrian, E., Alcoverro, T., 2007. Mortality of shoots of Posidionia oceanica following meadow invasion by the red alga Lophociadia lallemandii. Botanica Marina, 50, 8-13.

Bolwell, G.P., Davies, D.R., Gerrish, C., Auh, C.K., Murphy, T.M., 1998. Comparative biochemistry of the oxidative burst produced by rose and French bean cells reveals two distinct mechanisms. Plant Physiology, 116, 1379-1385.

Bouarab, K., Potin, P., Weinberger, F., Correa, J., Kloareg, B., 2001. The Chondrus crispus Acrochaete operculata host-pathogen association, a novel model in glycobiology and applied phycopathology. Journal of Applied Phycology, 13, 185193. 


\section{ACCEPTED MANUSCRIPT}

Boudouresque, C.F., Verlaque, M., 2002. Biological pollution in the Mediterranean Sea: invasive versus introduced macrophytes. Marine Pollution Bulletin, 44, 32-38.

Buia, M.C., Gambi, M.C., Zupo, V., 2000. Structure and functioning of mediterranean seagrass ecosystems: an overview. Biologia Marina Mediterranea, 7, 167-190.

Cebrian, E., Ballesteros, E., 2007. Invasion of the alien species Lophocladia lallemandii in the Eivissa-Formentera (Balearic Islands) Actes du $3^{\text {éme }}$ Symposium mediteranéen sur la végétation marine. Marseille 27-29 mars. pp 34-41.

Cobbett, C., Goldsbrough, P., 2002. Phytochelatins and metallothioneins: Roles in heavy metal detoxification and homeostasis. Annual Review of Plant Biology, 53, 159-182.

Collen, J., Pedersen, M., 1994. A Stress-Induced Oxidative Burst in EucheumaPlatycladum (Rhodophyta). Physiologia Plantarum, 92, 417-422.

Choo, K.S., Snoeijs, P., Pedersen, M., 2004. Oxidative stress tolerance in the filamentous green algae Cladophora glomerata and Enteromorpha ahlneriana. Journal of Experimental Marine Biology and Ecology, 298, 111-123.

Choo, K.S., Nilsson, J., Pedersen, M., Snoeijs, P., 2005. Photosynthesis, carbon uptake and antioxidant defence in two coexisting filamentous green algae under different stress conditions. Marine Ecology-Progress Series, 292, 127-138.

Dumay, O., Pergent, G., Pergent-Martini, C., Amade, P., 2002. Variations in caulerpenyne contents in Caulerpa taxifolia and Caulerpa racemosa. Journal of Chemical Ecology, 28, 343-352.

Elias, S.J., Arner, E.S., Zhong, L., Holmgren, A., 1999. In: L. Packer, Methods in Enzymatic Analysis. Oxidants and Antioxidants, Vol. 300 (pp 226-239). California: Academic Press. 


\section{ACCEPTED MANUSCRIPT}

Erickson, A.A., Paul, V.J., Van Alstyne, K.L., Kwiatkowski, L.M., 2006. Palatability of macroalgae that use different types of chemical defenses. Journal of Chemical Ecology, 32, 1883-1895.

Esterbauer, H., Schaur, R.J., Zollner, H., 1991. Chemistry and biochemistry of 4hydroxynonenal, malonaldehyde and related aldehydes. Free Radical in Biology and Medicine, 11, 81-128.

Ferrat, L., Pergent-Martini, C., Roméo, M., (2003) Assessment of the use of biomarkers in aquatic plants for the evaluation of environmental quality: application to seagrasses. Aquatic Toxicology, 65, 187-204.

Flohe, L., Gunzler, W.A., 1984. Assays for glutathione peroxidase. Methods in Enzymology, 105, 114-121.

Forman, H.J., Torres, M., 2002. Reactive oxygen species and cell signaling: respiratory burst in macrophage signaling. American Journal of Respiratory and Critical Care Medicine, 166, S4-8.

Geffard, A., Amiard-Triquet, C., Amiard, J.C., Mouneyrac, C., 2001 Temporal variations of metallothionein and metal concentrations in the digestive gland of oysters (Crassostrea gigas) from a clean and a metal-rich site. Biomarkers, 6, 91-107.

Gross, H., Goeger, D.E., Hills, P., Mooberry, S.L., Ballantine, D.L., Murray, T.F., Valeriote, F.A., Gerwick, W.H., 2006. Lophocladines, bioactive alkaloids from the red alga Lophocladia sp. Journal of Natural Products, 69, 640-644.

Halliwell, B., Gutteridge, J.M.C., 1999. Free radicals in Biology and Medicine (pp 106161). New York: Oxford University Press.

Küpper, F.C., Muller, D.G., Peters, A.F., Kloareg, B., Potin, P., 2002 Oligoalginate recognition and oxidative burst play a key role in natural and induced resistance of sporophytes of laminariales. Journal of Chemical Ecology, 28, 2057-2081. 


\section{ACCEPTED MANUSCRIPT}

Levine, R.L., Williams, J.A., Stadtman, E.R., Shacter, E., 1994. Carbonyl assays for determination of oxidatively modified proteins. Methods in Enzymology, 233. 346357.

Marba, N., Duarte, C.M., 1997. Decadal changes in seagrass (Posidonia oceanica) growth an environmental change in the Spanish Mediterranean littoral. Limnology and Oceanography, 42, 800-810.

McCord, J.M., Fridovich, I., 1969. Superoxide dismutase. An enzymic function for erythrocuprein (hemocuprein). Journal of Biological Chemistry, 244, 6049-6055.

Mitrovic, S.M., Pflugmacher, S., James, K.J., Furey. A., 2004. Anatoxin-a elicits an increase in peroxidase and glutathione S-transferase activity in aquatic plants. Aquatic toxicology, 68, 185-192.

Monserrat, J.M., Martinez, P.E., Geracitano, L.A., Amado, L.L., Martins, C.M., Pinho, G.L., Chaves, I.S., Ferreira-Cravo, M., Ventura-Lima, J., Bianchini, A., 2007. Pollution biomarkers in estuarine animals: Critical review and new perspectives. Comparative Biochemistry and Physiology-Part C Toxicology and Pharmacology, $146,221-234$.

Okamoto, T., Akaike, T., Sawa, T., Miyamoto, Y., van der Vliet, A., Maeda, H., 2001. Activation of matrix metalloproteinases by peroxynitrite-induced protein $S$ glutathiolation via disulfide $S$-oxide formation. Journal of Biological Chemistry, 276, 29596-29602.

Ozimek, T., Pieczynska, E., Hankiewicz, A., 1991. Effects of Filamentous Algae on Submerged Macrophyte Growth - a Laboratory Experiment. Aquatic Botany, 41, 309315.

Paul, V.J., Fenical, W., 1986. Chemical defense in tropical green algae, order Caulerpales. Marine Ecology-Progress Series, 34, 157-169. 
Ross, C., Küpper, F.C., Vreeland, V., Waite, J.H., Jacobs, R.S., 2005. Evidence of a latent oxidative burst in relation to wound repair in the giant unicellular chlorophyte Dasycladus vermicularis. Journal of Phycology, 41, 531-541.

Ross, C., Küpper, F.C., Jacobs, R.S., 2006. Involvement of reactive oxygen species and reactive nitrogen species in the wound response of Dasycladus vermicularis. Chemistry \& Biology, 13, 353-364.

Ruiz, J.M., Romero, J., 2001. Effects of in situ experimental shading on the Mediterranean seagrass Posidonia oceanica. Marine Ecology Progress Series, 215, 107-120.

Ruiz, J.M., Romero, J., (2003) Effects of disturbances caused by coastal constructions on spatial structure, growth dynamics and photosynthesis of the seagrass Posidonia oceanica. Marine Pollution Bulletin, 46, 1523-1533.

Scott, N., Hatlelid, K.M., Mackenzie, N.E., Carter, D.E., 1993. Reactions of Arsenic(Iii) and Arsenic(V) Species with Glutathione. Chemical Research in Toxicology, 6, $102-$ 106.

Shi, H., Sui, Y., Wang, X., Luo, Y., Ji, L., 2005. Hydroxyl radical production and oxidative damage induced by cadmium and naphthalene in liver of Carassius auratus. Comparative Biochemistry and Physiology-Part C Toxicology and Pharmacology, $140,115-121$.

Wojtaszek, P., 1997. Oxidative burst: An early plant response to pathogen infection. Biochemical Journal, 322, 681-692. 


\section{FIGURE LEGENDS}

Figure 1. Mean shoots densities in Posidonia oceanica meadows determined in October 2002 and 2006 in the control station and in 2006 in the epiphytized station. Values are expressed as mean shoots densties $/ \mathrm{m}^{2} \pm$ s.e.m. $\mathrm{N}=10$ samples in each location. $(*)$ Indicates significant differences respect control station in 2006, One-way ANOVA, $p<0.05$.

Figure 2. Representative image of Posidonia oceanica epiphyted by invasive Lophocladia lallemandii. 


\section{ACCEPTED MANUSCRIPT}

Table 1. Oxidative damage markers and antioxidant system in Posidonia oceanica

\begin{tabular}{lll}
\hline & P. oceanica & P. oceanica + L. lallemandii \\
\hline MDA (nmol/mg prot) & $5.75 \pm 0.27$ & $8.28 \pm 0.80 *$ \\
Protein carbonyl derivates (nmol/mg prot) & $4.57 \pm 0.47$ & $9.47 \pm 0.89 *$ \\
GSH (nmol/g prot) & $76.7 \pm 4.7$ & $101 \pm 6 *$ \\
Catalase (mK/mg prot) & $71.2 \pm 6.3$ & $91.3 \pm 6.9 *$ \\
GPX (nKat/mg prot) & $0.90 \pm 0.09$ & $1.71 \pm 0.17 *$ \\
SOD (pKat/mg prot) & $7.67 \pm 0.36$ & $9.73 \pm 0.45 *$ \\
$\mathrm{H}_{2} \mathrm{O}_{2}$ (pmol/min.mg prot) & $3.73 \pm 0.36$ & $4.62 \pm 0.42 *$ \\
\hline
\end{tabular}

Markers of oxidative damage (MDA concentration protein carbonyl derivates), GSH concentration, antioxidant enzyme activities (Catalase, GPX and SOD) and $\mathrm{H}_{2} \mathrm{O}_{2}$ generation in the leaves of Posidonia oceanica not epiphytized and epiphytized by Lophocladia lallemandii. Values are expressed as means \pm S.E.M, $\mathrm{n}=8$ samples in each location. (*) Indicates significant differences, One-way ANOVA, $p<0.05$. 
Figure 1

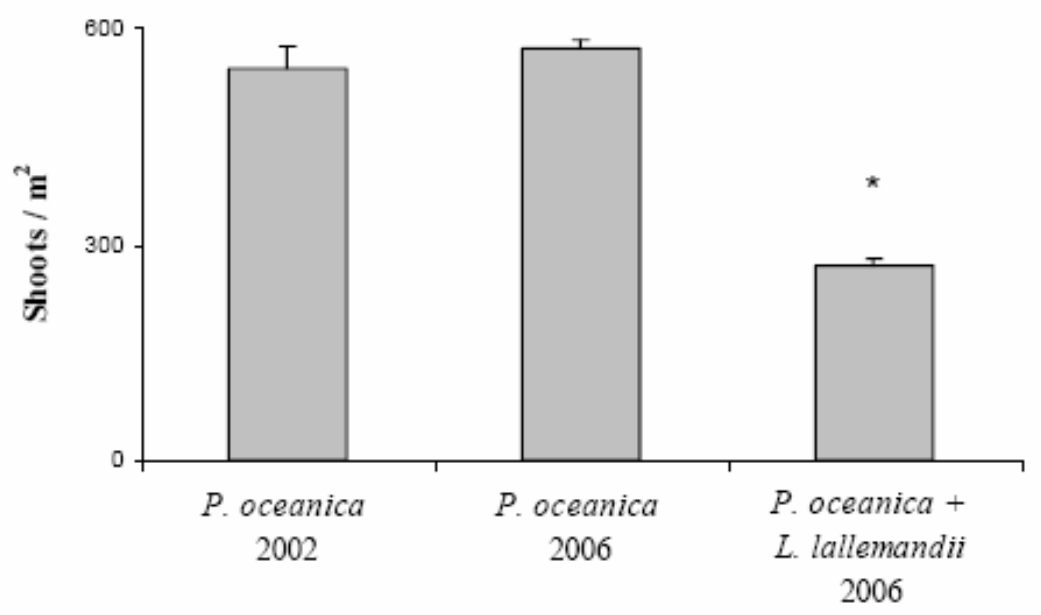




\section{ACCEPTED MANUSCRIPT}

Flgure 2
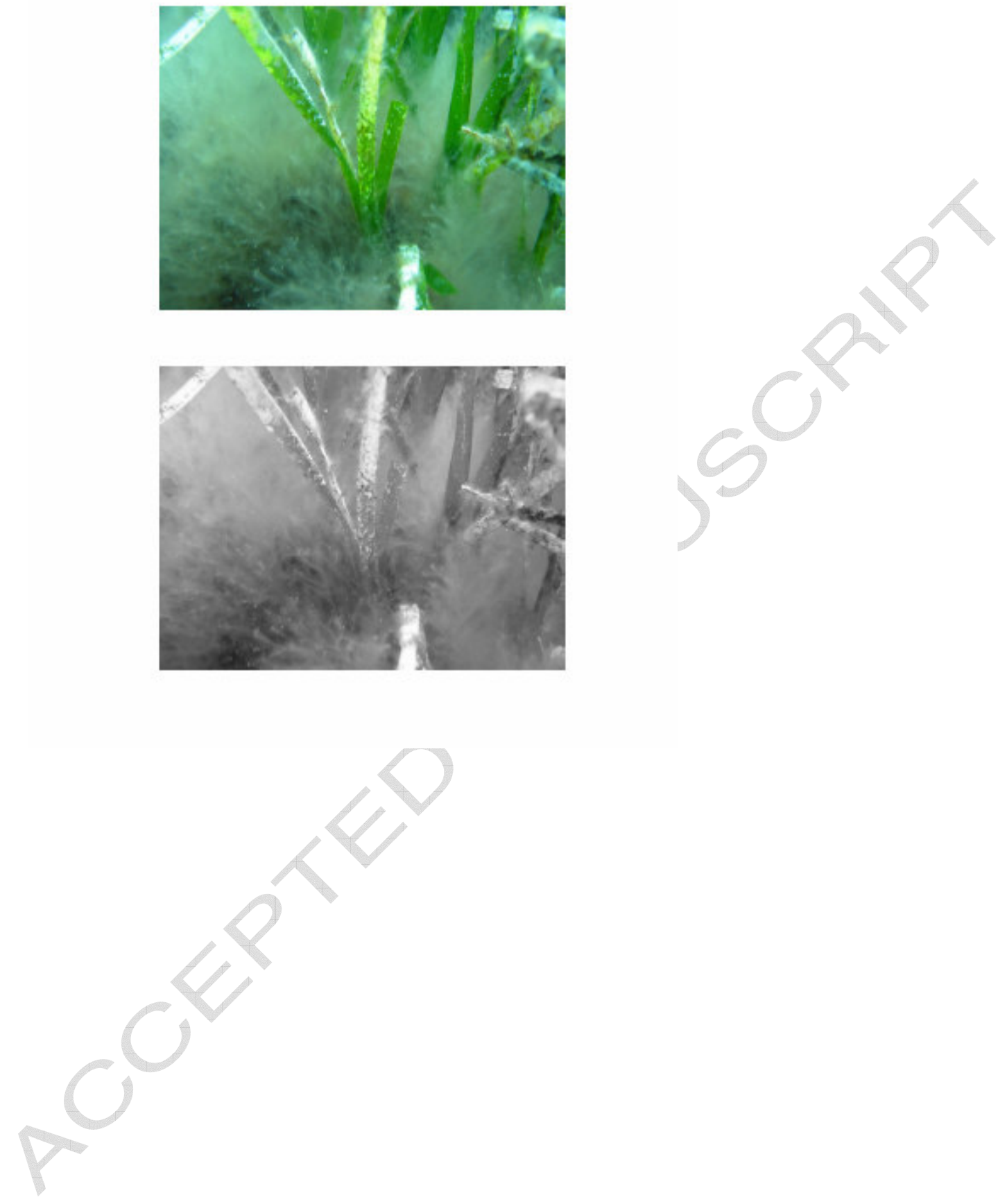